\title{
PENDAMPINGAN PERMODALAN USAHA KOPERASI NELAYAN PINTAR BANDA ACEH
}

\author{
Hamdani $^{*}$, Josi Farmiati ${ }^{2}$, Ismail ${ }^{3}$, Saiful Bahgia ${ }^{4}$, Hasbi $^{\mathbf{5}}$, Armanda Butar butar $^{\mathbf{6}}$ \\ ${ }^{1}$ Prodi Manajemen Keuangan Sektor Publik, Politeknik Kutaraja, Banda Aceh, Indonesia \\ ${ }^{2,3}$ Program Studi Administrasi Perkantoran, Politeknik Kutaraja, Banda Aceh, Indonesia \\ ${ }^{4}$ Program Studi Akuntan, Politeknik Kutaraja, Banda Aceh, Indonesia \\ ${ }^{5,6}$ Mahasiswa Prodi Manajemen Keuangan Sektor Publik, Politeknik Kutaraja, Banda Aceh \\ Email Korespondensi: hamdani.aceh@gmail.com
}

\begin{abstract}
ABSTRAK
Kegiatan Pengabdian kepada masyarakat $(\mathrm{PkM})$ pendampingan manajemen usaha dan permodalan bagi Koperasi Nelayan Pintar Banda Aceh telah menghasilkan pengetahuan baru bagi pengurus dalam mengatasi kebutuhan modal usaha yang diperlukan. Telah terjadi peningkatan kapasitas dalam mengelola aspek permodalan sehingga lebih efektif dan efesien. Selain itu kegiatan pendampingan ini juga telah berhasil terbangun hubungan kemitraan antara Koperasi Nelayan Pintar dengan pihak lembaga keuangan bank terutama bank pemerintah untuk mengakses Kredit Usaha Rakyat (KUR) Sektor Kelautan dan Perikanan yang telah diprogramkan. Metode pelaksanaan kegiatan ini bersifat kolaboratif dan aplikatif. Kegiatan pendampingan tersebut berlangsung pada Februari-April 2020.
\end{abstract}

Kata Kunci: Koperasi Nelayan, Permodalan Usaha, Kredit Usaha Rakyat

\begin{abstract}
Community Service Activities (PkM) assisting business management and capital for the Banda Aceh Smart Fisherman Cooperative have gathered new knowledge for the management in addressing the required business capital needs. There has been an increase in capacity in the aspect of capital so that it is more effective and efficient. In addition, this assistance activity has also succeeded in building a partnership relationship between the Smart Fishermen Cooperative and bank financial institutions, especially state banks to access programmed Marine and Fisheries Sector People's Business Credit (KUR). The method of implementing activities is collaborative and applicable. Assistance activities take place in February-April 2020.
\end{abstract}

Keywords: Fishermen Cooperative, Business Capital, People's Business Credit) 


\section{PENDAHULUAN}

Pandemi Covid-19 menimbulkan masalah besar terhadap perekonomian didalam negeri di Indonesia. Pandemi ini menimbulkan masalah sosial di tengah masyarakat khususnya disaat pemerintah melakukan berbagai langkah untuk melakukan pencegahan penyebaran Covid -19. Terutama berdampak pada usaha kecil menengah atau sektor informal yang menjadi salah satu bantalan bagi perekonomian Indonesia, ini dikarenakan, kebijakan pemerintah dalam mencegah penyebaran pandemi telah membatasi interaksi fisik antar masyarakat, sehingga berbagai aktivitas ekonomi secara informal menjadi terpukul termasuk sektor usaha Koperasi Nelayan.

Provinsi Aceh terletak di ujung barat Indonesia, secara geografis di kelilingi oleh laut yaitu Selat Malaka, Samudera Hindia dan pantai utaranya berbatasan dengan Selat Benggala. Provinsi Aceh berpotensi mengembangkan sektor perikanan menjadi andalan untuk menggerakkan perekonomian daerah (Neliyana et al., 2016). Pembangunan subsektor perikanan merupakan salah satu bagian dari pembangunan pertanian yang diarahkan untuk meningkatkan pendapatan masyarakat, swasembada hewani, peningkatan devisa negara dan menciptakan lapangan kerja yang produktif. Pembangunan subsektor perikanan diarahkan pada usaha peningkatan produksi perikanan yang mencakup perikanan laut, budidaya tambak dan perairan umum lainnya (Sulaiman, 2011).

Wilayah pesisir Aceh memiliki panjang garis pantai $1.660 \mathrm{~km}$ dengan luas wilayah perairan laut seluas $295.370 \mathrm{~km}^{2}$ terdiri dari laut wilayah (perairan teritorial dan perairan kepulauan) $56.563 \mathrm{~km}^{2}$ dan Zona Ekonomi Eksklusif (ZEE) $238.807 \mathrm{~km}^{2}$. Wilayah pantai dalam lautnya secara umum di pengaruhi oleh persimpangan arus dan gerakan Samudera Hindia, Selat Malaka dan Laut Cina Selatan yang berinteraksi dengan daratan pulau Sumatera, Semenanjung Malaka, Kepulauan Andaman dan Nicobar, sehingga menampakkan ekosistem laut di sepanjang pesisir Aceh sangat sesuai bagi kehidupan, biota laut (Neliyana et al., 2016).

Potensi sumberdaya ikan (stock assesment) di laut untuk perairan teritorial dan perairan kepulauan sebesar 220.090 ton dan di ZEE sebesar 203.320 ton atau total sebesar + 423.410 ton. Potensi lestari atau Maksimum Sustainable Yield (MSY) laut wilayah sebesar 110.045 ton dan ZEE dengan Total Allowable Catch (TAC) sebesar 80 persen atau +162.656 ton. Berarti total potensi lestari seluruhnya 272.707 ton dengan tingkat pemanfaatan baru mencapai 141.619,6 ton (51,93\%) tahun 2009 dengan kata lain masih terdapat peluang pengembangan sebesar 48,07 persen (Matindas \& Villanueva, 2017).

Potensi perikanan tangkap provinsi Aceh sempat mengalami krisis dan penurunan pada saat bencana Gempa Bumi dan Tsunami pada 26 Desember 2004. Hal tersebut mempengaruhi kondisi perikanan Aceh, seperti banyaknya jumlah Nelayan yang meninggal di pantai Barat dan Timur, rusaknya infrastruktur dan aset-aset nelayan, kondisi perumahan yang hancur. Tahapan pembangunan dan rekonstruksi Aceh memberi perhatian yang besar terhadap sektor perikanan. BRR sendiri sebagai lembaga pernerintah yang diberikan wewenang untuk melakukan rehabilitasi dan rekonstruksi Propinsi NAD dan Nias pasca tsunami yang ditetapkan melalui UU No.10 tahun 2005 telah melalukan berbagai kegiatan mulai dari perencanaan, pelaksanaan, koordinasi, monev, dan pengawasan yang terkait dengan pemulihan kembali kegiatan perikanan tangkap baik di Propinsi NAD maupun Nias.

Salah satu penyebab rendahnya produktivitas di sektor perikanan adalah eksploitasi perikanan di beberapa daerah telah melebihi kapasitas sumber dayanya atau disebut 
dengan tangkap lebih atau overfishing (Yaskun \& Sugiarto, 2017). Masalah tangkap lebih merupakan isu pokok yang terjadi di beberapa daerah penangkapan ikan. Gordon (1954) dalam Fauzi (2011) menyatakan bahwa sumber daya ikan pada umumnya open access, siapa saja bisa berpartisipasi tanpa harus memiliki sumber daya tersebut. Oleh karena itu, perikanan tangkap yang tidak terkontrol ini akan mengakibatkan economic overfishing. Gejala ini diyakini telah terjadi di Aceh, yang ditandai dengan tingginya penggunaan input, tetapi tidak dibarengi dengan peningkatan output dan returns secara proporsional yang maknanya usaha perikanan tangkap di Aceh semakin tidak efisien (Gunawan et al., 2019).

Prasarana dan sarana perikanan tangkap mengalami pertumbuhan seperti pelabuhan Perikanan, Pusat Pelalangan Ikan, Tempat Penampungan Ikan, cold storage, pabrik es, galangan kapal rakyat, unit/alat tangkap, dan pemukiman nelayan (Gunawan et al., 2019). Struktur armada dan usaha budidaya masih didominasi oleh skala kecil/tradisional dengan kemampuan IPTEK yang rendah. Sektor perikanan tangkap terdiri dari nelayan tetap dan nelayan tidak tetap sebanyak 164.080 jiwa, sektor budidaya sebanyak 56.300 jiwa, sektor pengolahan sebanyak 20.670 jiwa dan sektor pemasaran hasil perikanan melalui penjual ikan (mugee eungkoet) mencapai 16.250 jiwa (Statistik, 2003). Secara lebih rinci, sektor perikanan di Aceh menyerap 257.300 jiwa tenaga kerja, yang terdiri dari 4 (empat) sektor yaitu: Sektor penangkapan, Sektor budidaya, Sektor pengolahan, Sektor pemasaran hasil perikanan.

Berdasarkan data dari Dinas Perikanan Aceh, potensi perikanan laut Aceh mencapai 423.410 ton per tahun, sementara yang tergarap oleh nelayan tradisional Aceh baru sekitar 125.000 Ton. Artinya, nelayan Aceh baru mampu menggarap 37 persen dari potensi perikanan laut Aceh. Beberapa faktor yang menjadi kelemahan nelayan Aceh dalam mengoptimalkan hasil perikanan laut antara lain minimnya sarana dan prasarana. Unit teknologi penangkapan. Nelayan yang ada di Aceh umumnya adalah nelayan tradisonal yang tidak memiliki modal besar untuk mengembangkan usahanya menjadi lebih besar dan persoalan sumber daya manusia yang masih lemah sehingga penguasaan tentang teknik penangkapan dan pengelolaan ikan masih lemah (Iyan, 2014).

Produksi perikanan Provinsi Aceh tahun 2018 meningkat 6\% dibandingkan tahun 2017 atau mencapai 191.672 dibandingkan tahun sebelumnya sebesar 180.422 ton. Trend produksi perikanan Provinsi Aceh mengalami peningkatan sejak tahun 2014, kenaikan rata-rata 5 tahun terakhir (tahun 2013-2018) sebesar 3\% sedangkan 2 tahun terakhir (tahun 2013-2015) sebesar 6\%. Kontribusi terbesar dari produksi perikanan tangkap sebesar 150.155 ton, sedangkan produksi perikanan budidaya sebesar 41.557 ton.

Tren produksi perikanan tangkap mengalami kenaikan yang signifikan sejak tahu 2013 dengan kenaikan rata-rata yang sama pada tahun 2003-2011 dan tahun 2012-2013 yaitu sebesar $3 \%$. Untuk trend produksi perikanan budidaya mengalami kenaikan yang signifikan sejak tahun 2003, kenaikan rata-rata tahun 2003-2011 sebesar 5\% dan tahun 2012-2014 sebesar 21\%. Komoditi perikanan tangkap Provinsi Aceh yang terbesar tahun 2014 adalah tongkol komo (13.298 ton), cakalang (10.894 ton), layang (10.29 ton) dan kembung (10.269 ton). Sedangkan komoditi perikanan budidaya Provinsi Aceh terbesar tahun 2012 adalah bandeng (18.492 ton), udang windu (5.667 ton), ikan mas (4.412 ton) dan lele.

Berdasarkan hasil pengamatan kami, setiap pagi ketika kapal-kapal nelayan kembali dari melaut dan melakukan bongkar ikan di dermaga, banyak para nelayan buruh membantu melakukan pekerjaan jasa angkutan pembongkaran dengan upah Rp30.000 per keranjang yang isinya 40-50 kg. Jumlah nelayan buruh yang bekerja sebagai penyedia 
jasa bongkar dan angkutan ikan mencapai 112 orang, di antara mereka ada yang bekerja paruh waktu dan yang bekerja tetap. Proses kegiatan pendaratan ikan dan pelelangan dilakukan sejak pukul 06.00 WIB atau pada pagi hari sampai dengan jam 09.00.

Setiap hari jumlah kapal yang berlabuh di pelabuhan perikanan Lampulo, berdasarkan hasil wawancara kami dengan petugas UPTD Pelabuhan Perikanan Lampulo rata-rata mencapai 40-50 unit kapal. Setiap kapal yang pulang melaut dengan membawa hasil tangkapan dengan jumlah yang tidak sama, sesuai dengan besar kecilnya kapal, jenis alat tangkap dan jarak area penangkapan. Berat kotor kapal atau gross ton (GT) yang paling besar yang berlabuh di pelabuhan perikanan Lampulo mencapai 80-90 GT, namun jumlah kapal tersebut hanya ada 3 unit saja. Kapal dengan berat >80 GT mampu menampung ikan sebanyak 60-70 ton dengan masa melaut rata-rata 3-4 minggu. Menurut nelayan yang ada di pelabuhan mengatakan, rata-rata jumlah ikan yang didaratkan di pelabuhan perikanan Lampulo setiap harinya mencapai 150 ton.

Dengan area pemasaran yaitu Banda Aceh dan Aceh Besar hanya mampu menyerap sebanyak 30-40 ton ikan, baik untuk konsumsi rumah tangga maupun restoran, rumah makan, hotel dan home industry pengolahan ikan. Sedangkan kebutuhan pasar Banda Aceh, Aceh Besar sendiri mampu menyerap sebanyak 20-25 ton melalui pembelian oleh penjual ikan eceran dan pedagang ikan keliling (mugee ungkot) yang menggunakan kenderaan roda dua maupun sepeda. Jumlah mugee ungkot di pelabuhan perikanan Lampulo yang setiap paginya membeli ikan dari toke bangku (grosir) mencapai 2.000 orang dengan persediaan ikan yang mereka beli rata-rata 10-15 kg sesuai dengan keranjang yang mereka gunakan untuk alat mengecer ikan kepada masyarakat kota Banda Aceh atau sekitar area pemasaran mereka.

Permintaan ikan segar untuk kebutuhan unit pengolahan ikan skala rumah tangga sebagai bahan baku juga mengalami tren peningkatan. Menurut data Dinas Kelautan dan Perikanan (DKP) Aceh jumlah unit usaha pengolahan perikanan (UPI) di Banda Aceh, Aceh Besar dan sekitarnya mengalami pertumbuhan meningkat dari tahun-tahun sebelumnya, apalagi jika dibandingkan saat sebelum tsunami. Sehingga permintaan ikan segar oleh pelaku usaha pengolahan mencapai 10-20 ton per hari, terdiri dari beberapa jenis ikan, seperti cakalang, tongkol, tuna dan jenis ikan pelagis kecil lainnya.

Dengan demikian dapat dikatakan bahwa produksi ikan oleh nelayan yang melakukan pendaratan ikan di kawasan pelabuhan perikanan Lampulo mencapai 150 ton per hari, sedangkan yang mampu diserap oleh pasar baik lokal maupun ke Sumatera Utara hanya 100-120 ton. Sehingga ada kelebihan produksi mencapai 30 ton. Kelebihan inilah yang diserap oleh PT Lampulo Jaya Bahari yang ada di komplek pelabuhan Lampulo. Perusahaan ini membeli ikan dari nelayan dengan harga sangat murah atau di bawah harga pasar. Sementara nelayan tidak memiliki pilihan lain, jika tidak mau melepas pada harga yang diminta oleh perusahaan tersebut, maka ikan-ikan tersebut akan harus di buang kembali ke laut.

Berkaitan dengan rantai pemasaran ikan yang telah dijelaskan di atas, maka pengurus Koperasi Nelayan Pintar berupaya membeli seluruh hasil tangkapan nelayan dari kapal yang beroperasi dan bersandar di PPS Lampulo terutama hasil tangkapan kapal nelayan anggota koperasi, kemudian dipasok untuk memenuhi permintaan pasar sasaran yaitu para distributor Medan, Sibolga dan Jakarta, sehingga koperasi bukan hanya memiliki usaha penangkapan ikan tetapi juga usaha perdagangan ikan dalam skala besar (penampung). Dengan demikian, maka harga ikan yang diperoleh oleh pemilik kapal akan memberi keuntungan yang lebih besar termasuk pendapatan para nelayan buruh/ABK 
akan meningkat dan mereka juga merupakan anggota koperasi nelayan pintar. Di sisi lain Koperasi Nelayan membutuhkan modal kerja yang lebih besar.

Namun yang menjadi permasalahan adalah Koperasi Nelayan Pintar tidak mempunyai modal kerja untuk membeli ikan-ikan nelayan. Padahal dari aspek bisnis kegiatan perdagangan ikan sangat layak (feasible) dan menguntungkan (profitable). Sedangkan pihak pengurus sudah mengajukan permohonan ke pihak penyedia modal usaha namun ditolak. Berdasarkan permasalahan tersebut penulis melakukan kegiatan Pengbdian kepada Masyarakat (PkM) dengan judul "Pendampingan Permodalan Usaha Koperasi Nelayan Pintar Banda Aceh.” Kegiatan ini bertujuan untuk meningkatkan kapasitas Koperasi yang menjadi koperasi yang sehat, mandiri, dan sejahtera.

\section{METODE PENELITIAN}

Guna membangkit semangat para anggota koperasi ini dan juga mengatasi permasalahan sulit ditengah Covid-19, kita mengusulkan beberapa program untuk menghindari terjadinya kemacetan ekonomi, meningkatnya angka kemiskinan dan pengangguran serta memberdayakan kembali Koperasi Nelayan Pintar yang sedang tersendat, hal ini kita lakukan atas dasar kesepakatan dengan pihak mitra dan sesuai dengan kebutuhan dan keadaan mitra saat ini, diantara permasalahan yang menjadi perhatian serius saat ini adalah

Bimbingan Teknis dan pendampingan bagi Koperasi Nelayan Pintar dalam mengembangkan keberlangsungan usaha dengan adanya sumber daya manusia (SDM) yang handal untuk mengelola data dan membuat program-program strategis yang mampu bersaing secara profesional, kemudian dapat mengaplikasikan berbagai teknologi terbaru dalam menerapkan sistem pengembangan dan pembinaan koperasi dan mampu menganalisis kebutuhan permodalan, pemasaran (distribusi) secara elektronik ( $e$ commerce).

Untuk mencapai target tersebut tim pelaksana kegiatan Pengabdian kepada Masyarakat $(\mathrm{PkM})$ melakukan langkah-langkah sebagai metode implimentasi program yaitu: (1) identifikasi kebutuhan dengan melakukan survei ke lokasi rencana kegiatan kita menganalisa dan mendiskusikan kebutuhan apa saja yang dibutuhkan dan yang menjadi prioritas saat ini, dan kemudian kita lakukan diskusi lebih lanjut untuk mencocokkan dengan program saat ini dan coba berikan alternatif solusi untuk masa dating. (2) merancang sebuah system informasi manajemen mulai dari memilih metode, platform yang sesuai, membangun sistem pemograman, (3) pendampingan operasional yaitu memberikan pengetahuan konsep program akses modal bank, pendampingan teknis implementasi sistem informasi manajemen permodalan.

\section{HASIL PENELITIAN DAN PEMBAHASAN}

Koperasi Nelayan Pintar merupakan sebuah koperasi nelayan yang terbentuk dari cita-cita nelayan perikanan tangkap yang sejak tahun 2012 sudah tergabung dalam Kelompok Usaha Bersama (KUB) dan melakukan usaha penangkapan ikan dengan menggunakan armada kapal pukat dengan bobot 30 GT di perairan Aceh. Koperasi nelayan Pintar saat ini berkedudukan di komplek pelabuhan perikanan samudera Lampulo Banda Aceh dengan jumlah anggota 250 orang yang terdiri dari nelayan yang berada di kawasan Banda Aceh dan sebagian Aceh Besar.

Selain usaha penangkapan ikan dengan jumlah 18 unit armada kapal yang sudah berjalan, saat ini koperasi nelayan Pintar mengembangkan usaha perdagangan ikan lintas provinsi yaitu meliputi Provinsi Sumatera Utara dan ke Jakarta dengan jumlah pengiriman 
ikan sebanyak 5 ton per hari dan ditambah 25 ton per minggu. Adapun modal yang dimiliki oleh koperasi nelayan pintar periode tahun buku 2019 yaitu Rp990.429.600,(sembilan ratus sembilan puluh juta empat ratus dua puluh Sembilan ribu enam ratus rupiah) modal sendiri. Dari hasil usaha penangkapan, Koperasi Nelayan Pintar pada tahun buku 2015-2018 memperoleh pendapatan kotor sebesar Rp525.832.600,- (lima ratus dua puluh lima juta delapan ratus tiga puluh dua ribu enam ratus rupiah) dengan sisa hasil usaha (SHU) sebesar Rp81.332.600,- (delapan puluh satu juta tiga ratus tiga puluh dua ribu enam ratus rupiah) atau sekira $15,5 \%$.

Untuk memenuhi permintaan mitra usaha terhadap komoditas ikan, hasil analisis Koperasi Nelayan Pintar membutuhkan tambahan modal kerja yaitu sebesar Rp300.000.000,- (tiga ratus juta rupiah) yang digunakan untuk membeli ikan hasil tangkapan nelayan anggota koperasi maupun calon anggota lainnya dengan proyeksi pendapatan bersih sebesar Rp272.645.000,- (dua ratus tujuh puluh dua juta enam ratus empat puluh lima rupiah) perminggu atau sekira $71 \%$ per periode. Berdasarkan analisa kebutuhan modal tersebut Pengurus Koperasi Nelayan Pintar mengajukan pinjaman modal kerja kredit usaha rakyat (KUR) dengan plafond Rp300.000.000,- (tiga ratus juta rupiah) dengan suku bunga 9\% efektif anuitas dan jangka waktu angsuran selama 3 tahun kepada salah satu bank nasional milik BUMN yang ada di Banda Aceh.

Hasil kegiatan pendampingan yang diperoleh oleh Koperasi Nelayan Pintar adalah sudah terjalin kemitraan dengan perbankan. Hubungan kemitraan tersebut telah memudahkan pihak koperasi untuk mengelola modal usaha terlebih saat membutuhkan tambahan modal kerja, sehingga dengan cepat dapat direspon oleh pihak perbankan. Meningkatnya kepercayaan pihak perbankan terhadap pengurus koperasi tidak terlepas dari upaya pendampingan manajemen usaha yang telah dilakukan.

\section{KESIMPULAN DAN SARAN}

Hasil kegiatan Pengabdian kepada Masyarakat (PkM) ini dapat disimpulkan bahwa intervensi pendampingan terhadap pelaku usaha mikro kecil dan menengah (UMKM) dan Koperasi berpengaruh signifikan terhadap kemajuan usaha yang mereka kelola. Hal ini sejalan dengan hasil penelitian (Abd. Majid et al., 2018) yang menemukan bahwa fasilitasi permodalan ke bank dengan model pendampingan dari Pendamping UMKM berpengaruh secara positif dan signifikan terhadap persetujuan kredit.

Koperasi Nelayan Pintar yang umumnya beranggotakan nelayan yang berpendidikan rendah, maka disarankan agar meningkatkan kegiatan belajar dengan membuat program pendidikan yang dananya bersumber dari Sisa Hasil Usaha (SHU) yang disisihkan, minimal 2\% dari total SHU. Dengan demikian akan berdampak terhadap kemajuan koperasi secara menyeluruh dalam jangka panjang. Selain itu pemerintah juga diharapkan berperan dalam memberikan pembinaan dan pendampingan terutama pendampingan manajemen usaha dan penyusunan laporan keuangan. 


\section{DAFTAR PUSTAKA}

Abd. Majid, M. S., Hamdani, Nasir, M., \& Faisal. (2018). SMEs' credit demand and economic growth in Indonesia. Regional Science Inquiry.

Gunawan, H., Indra, I., \& Abdullah, F. (2019). Analisis Kebutuhan Es dan Dampaknya Terhadap Kualitas Ikan di Pelabuhan Perikanan Samudera Lampulo Banda Aceh. BIOTIK: Jurnal Ilmiah Biologi Teknologi Dan Kependidikan. https://doi.org/10.22373/biotik.v6i2.5617

Iyan, R. (2014). Analisis Komoditas Unggulan Sektor Pertanian di Wilayah Sumatera. Sosial Ekonomi Pembangunan.

Matindas, R. W., \& Villanueva, K. J. (2017). PULAU-PULAU TERLUAR DAN BATAS WILAYAH NASIONAL Status Delimitasi Batas Wilayah Nusantara. Jurnal Hukum \& Pembangunan. https://doi.org/10.21143/jhp.vol33.no1.1377

Neliyana, ., Wiryawan, B., Wiyono, E. S., \& Nurani, T. W. (2016). ANALISIS KELAYAKAN USAHA PERIKANAN PUKAT CINCIN DI PELABUHAN PERIKANAN PANTAI (PPP) LAMPULO BANDA ACEH PROPINSI ACEH (Analysis Financial Fisheries of Purse Seine in Lampulo Fishing Port Banda Aceh Provinsi Aceh). Marine Fisheries: Journal of Marine Fisheries Technology and Management. https://doi.org/10.29244/jmf.5.2.163-169

Statistik, B. P. (2003). Aceh Dalam Angka 2014. BPS Provinsi Aceh. https://doi.org/10.16309/j.cnki.issn.1007-1776.2003.03.004

Sulaiman, S. (2011). KEARIFAN TRADISIONAL DALAM PENGELOLAAN SUMBER DAYA PERIKANAN DI ACEH PADA ERA OTONOMI KHUSUS. Jurnal Dinamika Hukum. https://doi.org/10.20884/1.jdh.2011.11.2.188

Yaskun, M., \& Sugiarto, E. (2017). Potensi Hasil Perikanan Laut Terhadap Kesejahteraan Para Nelayan Dan Masyarakat. Studi Manajemen Dan Bisnis. 